\title{
A Study of Stress Factor and Its Impact on Students Academic Performance at Secondary School Level
}

\author{
Muhammad Saqib \\ M.Phil. Education University of Agriculture Faisalabad Sub-Campus Burewala-Vehari, Pakistan \\ Muhammad Naeem Naveed \\ M.Phil. Education University of Agriculture Faisalabad Sub-Campus Burewala-Vehari, Pakistan \\ Hina Irshad \\ M.Phil. Education University of Agriculture Faisalabad Sub-Campus Burewala-Vehari, Pakistan
}

\begin{abstract}
The existing study is entitled "a study of stress factor and its impact on student's academic performance at secondary level". The important motives of this study were to explore the stress impact on the students' academic performance. Stress is the main role in student's academic performance. The objectives of the study were to, investigate the type of stress links with student's performance, evaluate the impacts of stress on the academic performances of student's and differentiate the impacts of stress on the academic performances of male and female student's. The population of this study consisted of all the secondary school of district Vehari (Burewala, Mailsi and Vehari), Punjab, Pakistan. The total sample size was contained 360 male and female From this population the researcher was taken a sample of $(\mathrm{n}=12)$ secondary schools from each tehsil of district Vehari. The researcher was further divided schools into two group $(n=6)$ males and $(n=6)$ female schools. The researcher was taken $(n=10)$ students from each school selected as sample. The researcher was used simple random sampling technique for data collection. Five points Likert scale used in this research. 99\% respondents are responding about the factor of stress impact on their academic performance. After collected data, the data were analyzed by using Statistical Package for Social Sciences (SPSS) version 20. The tool (questionnaire) reliability of the collected data was 0.850 Cronbach alpha. In this study, a different test was applied to factor analysis and regression. Generally, the major findings of study exposed that there is a significant impact of stress on student's academic performance. The study concluded that major factors of stress is teacher and parents. The study also determined that there is same effect of stress on male and female students.
\end{abstract}

Keywords: Impact of Stress, Factor of stress on Male and Female. Learner Academic Performance

DOI: $10.7176 / \mathrm{JEP} / 10-13-01$

Publication date:May $31^{\text {st }} 2019$

\section{Introduction}

Stress is your body's approach to answering to any kind of demand or danger. When you sense risk whether it's real or imaginary, the body's defenses boost into high gear in a quick, automatic process known as the fight-orflight reaction or the stress answer. The stress reply is the body's way of defensive you. When working properly, it helps you stay focused, active, and attentive. In extra circumstances, stress can save your life, giving you additional strength to protect yourself. Stress can also help you rise to meet challenges. It's what keeps you on your toes during a presentation at work. But beyond a certain point, stress stops being helpful and starts causing major damage to your health, your mood, your productivity, your relationships, and your quality of life (Murff, 2005).

Stress usually denotes to two things, the psychological perception of pressure, on the one hand, and the body's reply to it, on the other, which involves manifold classifications, from breakdown to muscles to memory. Through hormonal signaling, the insight of hazard sets off an involuntary reply system, known as the fight-or-flight reply, that makes all animals to meet a challenge or flee from it. The demand for your event, such as an unexpected appearance of snake on your way or the fear of losing your work, enables you to take action including ordinary and courtesy, when the owner climbs you, the body, the sharp heart Rate and blood circulation, fat for high energy and promote sugar, focus, muscle preparation for the process, and more. It usually takes some time to start the body's stress reaction for the body when the stress begins (Womble, 2003).

Stress is the body's response to damaging conditions whether they are actual or apparent. When you feel endangered, a biochemical response happens in your body that agrees with you to perform in a way to prevent injury. This reaction is known as fight-or-flight or the stress reply. During stress answer, your heart rate increases, breathing quickens, muscles constrict, and pressure rises. You have become ready to act. It is how you defend yourself. Lifesaving as the stress retort is, it was meant to solve short term, life intimidating problems, not protracted problems. Prolonged or recurrent stimulation of the stress answer, a type of modern life, can have damaging physical and emotional effects, including heart sickness and sadness (Lyrakos, 2012). 
Stress can affect our emotional intelligence too. It affects our own feelings, the ability to understand our own feelings and communication. Stress can prevent us from controlling our emotions, associating with others, changing adaptation, and maintaining positive mode. Stress from a diversity of sources, such as confusion and poor classroom classrooms, or problems with family or fellows. Stress means that the methods of fighting it will help to promote the student's ability to learn. It is likely that changes notified in home and learning environment can increase the control and educational capacity of the students. Students can effectively improve minimum pressure and improve serious performance (Suldo at el., 2009).

Stress among students is multifactorial, arising from both academic and non-academic factors, including socio-cultural, conservational, and psychological qualities. Stress levels may intensify to important scopes in some students, to present with indications of nervousness particularly during tests and examination periods. Academic factors were the major cause of stress in most students, followed by physical, social, and emotional. Commonly of students with stress reported high scores of poor self-esteem, and about half scored high on depression scales. Stress to be related with poor academic performance (Barnes et al., 2003).

Stress occurs when there is a load on the person who is more than its assets. If the stress is tightened and extended, it can reduce educational performance, prevent the student's ability to stop and the substance of the substance and other potentially devastating The possibility of behavior can increase. Stress is considered to be a part of the life of students and can affect the students who have students in the strategy according to the demands of educational life. This is because education work always meets stress activity (Khan at el., 2013).

\section{Objective}

Following will be objective of study;

$>$ To identify the stress factors which affect the students' performance.

To differentiate the impacts of stress on the academic performances of male and female students.

\section{Review of Literature}

Zheng et al. (2002) study that psychiatric stress has also stimulated stress response. The central nervous system and association have system seriously show emotional, psychological and social effects. It was shown that the way a person thinks of a tension and feelings creates a neuroendocrine reaction. Physical and psychological stress has shown tension response. Physical pressure has described as an external environment change or body change, which causes chemical or physical disorders in cells, which require some reactions. Psychiatric stress may result in reactions or reactions. A response to the stress is a physical reaction due to a psychological stress.

According to Akgun and Ciarrochi (2003) stress has a difficult process that is introduced by awareness about the situation or conditions. The physical response to tension as a normal adjustment syndrome. Contains three stages, common adaptation describes the complex body's response to a real or intelligent stress. Within the reaction phase, one is considered to be a stress and begins a war or flight. In this period of stress, the release of body shortest road releases, enhance sympathetic nervous system activity. The stage of resistance according to this study triggered by physical deposits so that individual pressure on stress can increase. At this stage, the response to mail or flight is disabled, and the sympathetic nervous system activities return to the primary line. If a clear disorder continues, people can reach fatigue stage where people lose the ability to face stress.

There are several tasks that are measured by memory stress. To be more precise, these surveys have been handled to work memory naturally, and as long as there is no volume in the text, the readers should consider general memory references as memory references. Many investigations in the review do not make this difference clear. Usually, the long term memory remains in tension, however, different functions are memory elements more powerful. Teachers have given a unique opportunity to observe children and respond to individual needs. Because teachers work with children on a regular basis because they usually have a significant change in the first out of the family to note. As a result of stress, students can completely change their behavior and work habits (Helton, 2004).

Educational success is an experiment to be a direct result of learning. This is the main pointer that is learned. Academic performance is the fulfillment of the conscience of parents and friends. Some researchers have formed a relationship between the result of diagnosis and stress or the separation of performance problems or improvements. Joint awareness has confirmed that behavior was directly related to the demand of a person to develop depression mode after negative conditions. Students whose attitude was positive than those who had had negative effects with more negative behavior as a negative situation. This measure is either by examination or continuous evaluation and the purpose may be different from any person or organization (Abela and Alessadro, 2002).

Teachers experience Secondary school has a significant impact on student performance at the school level. Experienced teachers have a comfortable background of integration experience and can help develop awareness and ideas regarding education and education, they are open to improving and are less powerful in the classroom (Stringfield and Teddlie, 1991). Teachers experience and student performance were that students have stabilized more experienced teachers, it can be achieved at a high level because their teachers have content and materials to 
cope with different classroom issues. Classroom organization has mastered (Erkutlu and Chafra, 2006).

In parent participation, culture and society can vary from the public. Parents can be a variety of different types, which can be varied on their child's educational performance. Parents expectations have more impact on student education results (Ashcraft, 2002). Parental involvement was ranked in four broad topics in children's school-based activities, child's responsibility for child-based activities, the direct concentration of children's educational activities and indefinite detention of children's educational activities. Is. It's true that the parent's level varies between parents (Benson, 2006).

Research by Brahier (2000) has shown that the positive effects of homework generally reduce negative effects. Its study shows that the teacher is assigned to the main beliefs in assigning homework performance and evaluation. The homework assignment course should be consistent with the overall teaching strategy and evaluation. On the final grade path, Homework was counted, the teacher felt that the students took it seriously. Generally, this reviewer examined the maximum impact that he influenced the student's educational performance in schools and provided educational education in school education, educational performance and school and Students' educational performance impact the impact of outside school factors and effects.

Its study has shown that parents' ideas follow Para graphical effects about child's educational success, much more than parent's responsibilities, such as participate in school events. Parents' expectations affect children's results in many ways. Parents' expectations are more to influence their children when parents understand the relationship and are characterized by mercy. Parent's expectations have a direct emotional effect (Ginsburg, 2007). Parents' expectations are of their children's school capabilities, to influence the capabilities and performance of their children, and early developments are held to continue through the child's school years. The group organized the measurement of the measurement of the measurement of measuring social performance. As emphasized in the study of the family member, the student's educational future increases then define the factors of dealing with such possibilities (Entwisle et al., 2005).

\section{Methodology}

The study was descriptive in nature. Descriptive research concerned with how what is or what exists is related to some preceding event that has influenced or affected a present condition or event. In this study, survey method was used for collecting data through questionnaire. In order to measure or describe any generalized features. The population of this study consisted of all the secondary school of district Vehari (Burewala, Mailsi and Vehari), Punjab, Pakistan. ( $\mathrm{N}=157)$ Secondary school in Vehari District, $(\mathrm{N}=80)$ males and $(\mathrm{N}=77)$ females. Total population of students in District Vehari are $(\mathrm{N}=93511)$ enrolled. In this total population $(\mathrm{N}=51639)$ are male students and $(\mathrm{N}=41872)$ are females in District. This data was retrieved from the School Department Government of Punjab web site. The researcher was used simple random sampling and stratified random sampling technique for data collection. From this population the researcher was taken a sample of $(\mathrm{n}=12)$ secondary schools from each tehsil of district Vehari. The researcher was further divide schools into two group $(\mathrm{n}=6)$ males and $(\mathrm{n}=6)$ female schools. The researcher was taken $(n=10)$ students from each school selected as sample. The total sample size was contained 360 male and female.

Distribution of the sample (Combined)

\begin{tabular}{ccccccc}
\hline Type of school & Gender & Class & Vehari & Burewala & Mailsi & Total \\
\hline \multirow{3}{*}{ Public } & Male & $10^{\text {th }}$ & 60 & 60 & 60 & 180 \\
\cline { 2 - 7 } & Female & $10^{\text {th }}$ & 60 & 60 & 60 & 180 \\
\hline & Total & & 120 & 120 & 120 & 360 \\
\hline
\end{tabular}

After an extensive review of related literature, a questionnaire was self-developed for investigating the impact of stress on students' academic performance at secondary level. Part I contained demographic information such as gender. Part II consisted of 52 close ended questions. Students' academic stress questionnaire (SASQ) was prepared by the researcher, it was used by researcher for collecting data about independent variable. For close ended questions, five-point Likert scale (from strongly disagree to strongly agree). The value of Cronbach alpha was 0.850 , which shows high level of reliability of the scale (questionnaire). After the collection of data, data was analyzed. Statistical package for social sciences was used for analysis of data. Find out the frequencies, Percentage and Mean score value. The result of paired Regression was tested on the basis of statistically significance level of 0.05 .

\section{Result and Discussions}

The following results show that independent sample t-test was run out gender wise impact of stress on student's academic performance at secondary level. The result of below table shows that significant noticed between male and female students on impact of stress. The teacher stress t-value is -0.267 and $p$-value is 0.789 . The academic result $t$-value is 0.928 and $p$-value is 0.353 . The home strictness $t$-value is -0.116 and $p$-value is 0.907 . the family pressure $t$-value is 0.502 and $p$-value is 0.615 . the Future stress $t$-value is -1.612 and $p$-value is 0.107 . The below data shows that there is no impact of stress between male and female students. This statistically measurement 
shows that male and female have facing same type of stress from their academic career.

t-test results comparing the impact of stress on male and female students Group Statistics

\begin{tabular}{|c|c|c|c|c|c|}
\hline Statements & Gender & $\mathbf{N}$ & Mean & $\mathbf{T}$ & P value \\
\hline \multirow[t]{2}{*}{ Teacher Stress } & Male & 180 & 4.600 & \multirow[t]{2}{*}{-0.267} & \multirow[t]{2}{*}{0.789} \\
\hline & Female & 180 & 4.607 & & \\
\hline \multirow[t]{2}{*}{ Academic Result } & Male & 180 & 4.573 & \multirow[t]{2}{*}{0.928} & \multirow[t]{2}{*}{0.353} \\
\hline & Female & 180 & 4.554 & & \\
\hline \multirow[t]{2}{*}{ Family Pressure } & Male & 180 & 4.551 & \multirow[t]{2}{*}{0.502} & \multirow[t]{2}{*}{0.615} \\
\hline & Female & 180 & 4.533 & & \\
\hline \multirow{2}{*}{$\begin{array}{c}\text { Future } \\
\text { Stress }\end{array}$} & Male & 180 & 4.412 & \multirow[t]{2}{*}{-1.612} & \multirow[t]{2}{*}{0.107} \\
\hline & Female & 180 & 4.490 & & \\
\hline
\end{tabular}

The hereunder data elaborate that impact of stress on student's academic performance. The $(F=773.75, p=.000)$ value is significant. The value of independent variables represents that one unit increase in independent variable will increase $(B=0.796)$ in dependent variable. The value of $(t=7.445, p=.000)$ is also significant.

\begin{tabular}{|c|c|c|c|c|c|c|c|}
\hline Dependent Variable & $\begin{array}{l}\text { Independent } \\
\text { Variable }\end{array}$ & $\mathbf{B}$ & t & Sig & $\mathbf{F}$ & $\mathbf{R}$ & $\begin{array}{c}\mathbf{R} \\
\text { Square }\end{array}$ \\
\hline $\begin{array}{c}\text { Students } \\
\text { Performance }\end{array}$ & Stress & .796 & 7.445 & .000 & 773.75 & .796 & .633 \\
\hline
\end{tabular}

\section{Conclusions}

Based on data analysis, the following conclusions were made:

Most teachers punish the students' weakness in a classroom. Many teachers properly provide feedback to students learning. Teachers are also motivated by students and classroom attention during lecture. Often the teacher failed to clarify the purpose of the lesson during class education. There is no good way to educate them that emphasize students. The mainstream of teachers is given many exercises and tests to the students. Most teachers do not understand the teaching material properly during their lecture. Teachers do not influence students, their learning capabilities. The gap of communication between teachers and head teachers affects their learning. Most teachers make a healthy environment to communicate with all students in the classroom. Teachers show their social economic status that affects students learning. Students have no chance to meet their teacher in free time for learning purposes. Students feel that they will not be able to understand some teacher's teaching methods. Most students responded that they felt that their teachers respected them in the classroom.

\section{Recommendations}

The current research was considered to indicate the impact of stress on the student's educational performance, Stress is the highest price for success. Male and female students are not significantly different in their academic stress scores. To reduce the factors that affect student's educational performance in secondary schools, the related body has to work on students issue seriously. Teachers should provide good teaching methods and increase learning skills for students. Teachers should not force students for tuition. Teachers should provide appropriate instructions on the examination and test. Parents and family have played role in student educational achievements. Parents should provide all the school needs and should also take check and balance of their children. Parents should attend parents meeting regularly. Parents and family should encourage to their children for homeworking. Secondary schools should break any obstacles that prevent parents from joining, and they must work carefully to improve their parents 'interactions with school and their children' school work. Schools provide opportunities for parents to collaborate with their parents, by visiting the school and invited an environment. In schools, capable, reliable, experienced teachers are important inputs to ensure the quality of education. However, teacher's capability and dedicated, parent participation in school, class size and school facilities were one of the tasks in schools to head even teaching learning process. Students should be aware that regular examinations can take short breaks while working, and relaxing for a moment.

\section{Reference}

Barnes, V. A., Bauza, L. B., \& Treiber, F. A. (2003). Impact of stress reduction on negative school behavior in adolescents. Health and Quality of Life Outcomes, 1(1), 10.

Khan, M. J., Altaf, S., \& Kausar H. (2013). Effect of Perceived Academic Stress on Students' Performance. Journal of Social Sciences, 7(2), 146-151.

Lyrakos, D. G. (2012). The impact of stress, social support, self-efficacy and coping on university students, a multicultural European study. Psychology, 3(02), 143. 
Murff, S. H. (2005). The impact of stress on academic success in college students. ABNF Journal, 16(5), 102.

Suldo, S. M., Shaunessy, E., Thalji, A., Michalowski, J., \& Shaffer, E. (2009). Sources of stress for students in high school college preparatory and general education programs: Group differences and associations with adjustment. Adolescence, 44(176), 925.

Womble, L. P. (2003). Impact of stress factors on college students' academic performance. Undergraduate journal of Psychology, 16(1), 16-23.

Zheng, J. L., Saunders, K. P., Shelley, M. C., \& Whalen, D. F. (2002). Predictors of academic success for freshmen residence hall students. Journal of College Student Development, 43(2), 267-283.

Akgun, S., and Ciarrochi, J. (2003). Learned resourcefulness moderates the relationship between academic stress and academic performance. Educational Psychology, 23(3), 287-294.

Helton, W. S. (2004). Validation of a short stress state questionnaire. Proceedings of the Human Factors and Ergonomics Society, 48, 1238-1242.

Abela, J.R., and. Alessandro, D. U. (2002). Beck's cognitive theory of depression: A test of the diathesis-stress and causal mediation components. British Journal of Clinical Psychology, 41(2), 111-128.

Stringfield, S., and Teddlie, C. (1991). School, Classroom and students' Level Indicators of Rural School Effectiveness. A Journal of Research in Rural Education, 7(1), 15-28.

Erkutlu H. V., and Chafra, J. (2006). Relationship between leadership power bases and job stress of subordinates. example from boutique hotels, Manage. Res. News, 29(5), 285- 297.

Ashcraft, M. H. (2002). Math anxiety: Personal, educational, and cognitive consequences. Current directions in psychological science, 11(5), 181-185.

Benson, P. R. (2006). The impact of child symptom severity on depressed mood among parents of children with ASD: The mediating role of stress proliferation. Journal of autism and developmental disorders, 36(5), 685695.

Brahier, D. (2000). The role of graphing calculators in advancing discourse. Focus on Learning Problems in Mathematics, 22(3/4), 81-92.

Ginsburg, K. R. (2007). The importance of play in promoting healthy child development and maintaining strong parent-child bonds. Pediatrics, 119(1), 182-191.

Entwisle, D. R., Alexander, K. L., and Olson, L. S. (2005). First grade and educational attainment by age 22: $A$ new story. American Journal of Sociology, 110, 1458-1502. 